\title{
Profile of physically active elderly women with urinary incontinence
}

\author{
Perfil de idosas fisicamente ativas com incontinência urinária
}

\section{Perfil de adultas mayores físicamente activas con incontinencia urinaria}

\author{
Gabriela Gonçalves Pereira da Silva', Ana Paula Krüger ${ }^{2}$, Edmundo de Drummond Alves Junior ${ }^{1}$, \\ Jonas Lírio Gurgeß ${ }^{3}$, Alessandra Conceição Leite Funchal Camacho ${ }^{4}$
}

\section{ORCID IDS}

Silva GGP (D) https://orcid.org/0000-0003-1303-1052

Krüger AP (D) https://orcid.org/0000-0001-8784-9020

Alves Junior ED (D) https://orcid.org/0000-0003-1664-1542

Gurgel JL (D http://orcid.org/0000-0002-9355-7793

Camacho ACLF (D) http://orcid.org/0000-0001-6600-6630

\section{HOW TO CITE}

Silva GGP; Krüger AP; Alves Junior ED; Gurgel JL; Camacho ACLF. Profile of physically active elderly women with urinary incontinence. ESTIMA, Braz. J. Enterostomal Ther., 16: e2418. doi: 10.30886/estima.v16.560.

\begin{abstract}
Objective: To design the profile of active elderly women with urinary incontinence (UI) participating in a physical activity program according to sociodemographic characteristics, health conditions, life habits and conditions associated with urinary loss. Methods: A quantitative, cross-sectional, non-probabilistic study of 59 active elderly women. The elderly woman whose score was $\geq 3$ according to the International Consultation on Incontinence Questionnaire - Short Form (ICIQ-SF) was considered incontinent. A descriptive analysis was performed by calculating the absolute and relative frequencies. Results: Predominant age between 70 and 79 years (44.1\%), widows (32.2\%), white (59.3\%), complete high school (40.6\%) and living alone (52.5\%). The largest proportion never smoked (64.4\%) or drank (47.5\%), it did not fall in the last year (64.4\%), hypertensive (55.9\%), had between one and three births (71.2\%), were overweight (42.4\%) and it did not use an intimate protector (67.8\%). Urgency UI was more frequent (50.9\%), small amount losses (54.3\%), frequency $\leq 1$ time per week (42.6\%), complaint of nocturia (81.4\%) and time of UI between 1 and 4 years (64.4\%). Conclusion: The study made it possible to design the profile of active elderly women with UI, which in this study resemble those found in the literature. It is important to emphasize the importance of multidisciplinary work in the search for preventive actions and specialized treatments, aiming to maintain and/or improve the quality of life of incontinent elderly.
\end{abstract}

DESCRIPTORS: Urinary incontinence; Exercise; Aging; Stomatherapy.

\footnotetext{
${ }^{1}$ Universidade Federal Fluminense, Departamento de Educação Física e Desporto, Laboratório de Envelhecimento e Atividade Física - Niterói/RJ - Brazil.

¿Universidade do Estado de Santa Catarina - Florianópolis/SC - Brazil.

${ }^{3}$ Universidade Federal Fluminense - Departamento de Educação Física e Desporto, Laboratório de Biodinâmica - Niterói/RJ - Brazil.

${ }^{4}$ Universidade Federal Fluminense - Laboratório de Pesquisa em Saúde e Enfermagem no Cuidado às Pessoas em Condições Agudas e Crônicas - Niterói/RJ - Brazil.

Corresponding author: Gabriela Gonçalves Pereira da Silva | Rua Presidente Pedreira, 189/1004 | ZIP Code: 24210-470 - Niterói/RJ Brazil | E-mail: silva.ggp@gmail.com

Received: Nov. 302017 | Accepted: Jun. 042018
} 


\section{RESUMO}

Objetivo: Traçar o perfil de idosas ativas com incontinência urinária (IU) participantes de um programa de atividade física segundo características sociodemográficas, condições de saúde, hábitos de vida e condições associadas à perda urinária. Métodos: Estudo quantitativo, transversal, não probabilístico, composto por 59 idosas ativas. Foi considerada incontinente a idosa cujo escore foi $\geq 3$ segundo o International Consultation on Incontinence Questionnaire - Short Form (ICIQ-SF). Realizou-se análise descritiva pelo cálculo das frequências absoluta e relativa. Resultados: Idade predominante entre 70 e 79 anos (44,1\%), viúvas (32,2\%), brancas (59,3\%), ensino médio completo (40,6\%) e morando sozinhas (52,5\%). A maior parcela nunca fumou $(64,4 \%)$ ou bebeu $(47,5 \%)$, não sofreu queda no último ano (64,4\%), era hipertensa (55,9\%), teve entre um e três partos (71,2\%), tinha sobrepeso (42,4\%) e não usava protetor íntimo (67,8\%). Foi mais frequente a IU de urgência (50,9\%), perdas em pequenas quantidades (54,3\%), frequência $\leq 1$ vez por semana (42,6\%), queixa de noctúria $(81,4 \%)$ e tempo de IU entre 1 e 4 anos $(64,4 \%)$. Conclusão: $O$ estudo possibilitou traçar o perfil de idosas ativas com IU que, neste estudo, assemelha-se aos encontrados na literatura. Salienta-se a importância da atuação multiprofissional na busca por ações preventivas e tratamentos especializados, visando manter e/ou melhorar a qualidade de vida de idosos incontinentes.

DESCRITORES: Incontinência urinária; Exercício; Envelhecimento; Estomaterapia.

\section{RESUMEN}

Objetivo: Trazar el perfil de adultas mayores activas con incontinencia urinaria (IU) que participan en un programa de actividad física según características sociodemográficas, condiciones de salud, hábitos de vida y condiciones asociadas a la pérdida urinaria. Métodos: Estudio cuantitativo, transversal, no probabilístico, compuesto por 59 adultas activas. Fue considerada incontinente a la adulta mayor cuyo escore fue $\geq 3$ según el International Consultation on Incontinence Questionnaire - Short Form (ICIQ-SF). Se realizó un análisis descriptivo por el cálculo de las frecuencias absoluta y relativa. Resultados: Edad predominante entre 70 y 79 años (44,1\%), viudas (32,2\%), blancas (59,3\%), enseñanza secundaria completa (40,6 \%) y que viven solas (52,5\%). La mayoría nunca fumó (64,4 \%) o bebió (47,5\%), no sufrió caída en el último año (64,4 \%), era hipertensa (55,9\%), tuvo entre uno y tres partos (71,2\%), con sobrepeso (42,4\%) y no usaba protector íntimo (67,8 \%). Fue más frecuente la IU de urgencia (50,9\%), pérdidas en pequeñas cantidades (54,3\%), frecuencia $\leq 1$ vez por semana (42,6\%), queja de nicturia (81,4\%) y tiempo de IU entre 1 y 4 años (64,4\%). Conclusión: El estudio hizo posible trazar el perfil de adultas mayores activas con IU que, en este estudio, se asemeja a los encontrados en la literatura. Se destaca la importancia de la participación multiprofesional en la búsqueda de acciones preventivas y tratamientos especializados, con el fin de mantener y/o mejorar la calidad de vida de adultos mayores incontinentes.

DESCRIPTORES: Incontinencia urinaria; Ejercicio; Envejecimiento; Estomaterapia.

\section{INTRODUCTION}

A frequently observed symptom in the elderly is urinary incontinence (UI). Defined by the International Continence Society (ICS) as any involuntary loss of urine, it is one of the major geriatric syndromes and has a multifactorial etiology ${ }^{1}$. UI is classified into three main types: by effort (UIE), when preceded by increased intra-abdominal pressure (such as coughing, sneezing, laughter, physical activity); by urgency (UIU), with loss of urine preceded by voiding urgency; or mixed (UIM), when it occurs both by effort and by urgency ${ }^{1}$. The consequences of the symptoms of urine loss affect the social, economic, psychological, sexual and professional spheres of the individual and can accentuate cases of social isolation and depression ${ }^{2}$. In addition, its cause shame and embarrassment to those affected by $\mathrm{it}^{2,3}$, which causes them to be underdiagnosed and/or diagnosed and treated late ${ }^{2,4}$.
Some physiological alterations of aging favor the reduction of the sphincter function and the appearance of UI, such as the decrease in the contractility of the detrusor muscle and the urethral closure pressure, the increase of the residual and prostatic volume ${ }^{1,5}$, besides the intensification of important events, such as the nocturnal production of urine and the incidence of urinary infections. According to the signaled motives, its prevalence is higher in the elderly and ranges from $8 \%$ to $60 \%$, depending on the profile of the studies performed ${ }^{2,4-7}$. Between the genders, the predominance of UI is found in women and is justified by the lower length of the urethra compared to men, as well as the hormonal changes due to menopause and the consequences of vaginal births in the pelvic floor ${ }^{4-5,7}$. The literature presents other risk factors: race, parity, family history of UI, obesity, intestinal 
constipation, smoking, hypertension, treatment for prostate cancer, cerebrovascular accident, diabetes mellitus, pelvic surgeries, cognitive disorders and physical disability ${ }^{3-5,8-9}$.

The relationship between physical activity and UI is still controversial. For some authors, non-sedentarism and regular practice of physical activities are understood as protective factors for the appearance of $\mathrm{UI}^{2,4,9}$, while promoting regulation of body weight, strengthening of muscles and maintenance of physical capacity ${ }^{10}$. On the other hand, vigorous physical activities are understood as an important risk factor ${ }^{5}$, especially those with high impact ${ }^{11-12}$, since they affect the pelvic floor muscles (PFM) and damage its sustentation, suspension and containment ${ }^{13}$. As a limitation, however, most of these studies have as adults high-performance athletes, which makes this kind of comparison difficult.

Although many risk factors for UI are clear in the literature, little is known about the physically active elderly female population and its characteristics ${ }^{13}$. Therefore, it is relevant to investigate the profile of this population and to understand the factors associated with UI in this public, in order to direct specific actions through the practice of physical activities and health education

\section{OBJECTIVE}

To design the profile of active elderly women with UI in a program of physical activity according to sociodemographic characteristics, health conditions and life habits and conditions associated with urinary loss.

\section{METHODS}

This is a quantitative cross-sectional study. The sample was non-probabilistic of convenience, composed of elderly women attending a fall prevention program in the city of Niteroi, state of Rio de Janeiro, with a total of 167 people.

This program has been developed since 2001 and aims to prevent falls through physical activities from the perspective of leisure, playfulness and intergenerationality ${ }^{14}$. Power, stretching and gym workshops are offered, each lasting 1 hour and 3 times a week in the morning and afternoon shifts. Currently, the program serves 167 adults and seniors of both genders, $90 \%$ of whom are elderly women. The class planning is based on the systematization of physical exercises and ludic activities focusing on the improvement of physical valences associated with fall events, such as balance, strength and flexibility ${ }^{14}$. In the strength workshop, activities are offered that contribute to the strengthening of large muscle groups; stretching exercises prioritize exercises that improve flexibility and promote greater range of movement for students; and in gymnastics activities are proposed that contemplate the objectives of both workshops previously described.

The sample was composed according to the inclusion criteria:

i. To be enrolled in a project workshop;

ii. Be woman;

iii. Age 60 or older;

iv. Reporting UI symptoms; and

v. Agree to participate in the study.

As an exclusion criterion, the individual was not evaluated by medical determination or with a number of absences greater than four in the last month.

The data were self-referenced and collected through an individual interview using a semi-structured form, based on the literature and prepared by the researchers. The UI was evaluated through the International Consultation on Incontinence Questionnaire - Short Form (ICIQ-SF) ${ }^{15}$. It is a brief selfadministered questionnaire capable of qualifying urine loss in patients of both genders and its impact on the individual's quality of life ${ }^{15}$. The overall score ranges from 0 to 21 and is a result of the sum of the scores of questions 3,4 and 5. In this study, the elderly woman who presented a general score greater than or equal to 3 it was considered incontinent ${ }^{6}$.

The study variables include socio-demographic characteristics (age, marital status, race, schooling, live alone), health conditions and life habits (smoking, alcoholism, history of falls in the last 12 months, fecal incontinence, intestinal constipation, comorbidities, number of births, births ways, number of daily medications, water intake, nutritional status, type of activity practiced in the project) and conditions associated with loss of urine (UI classification, complaining time, nocturia, use of protector, frequency, quantity, type and situations of loss evaluated through ICIQ-SF ${ }^{15}$ ).

All the volunteers were considered active, since they perform at least 150 minutes of weekly activity moderate ${ }^{16}$ in the project. The body mass index (BMI) was used to characterize the nutritional status and had as cutoff points: low weight $\leq 22 \mathrm{~kg} / \mathrm{m}^{2}$; adequate weight $>22$ and $<27 \mathrm{~kg} / \mathrm{m}^{2}$; and overweight $\geq 27 \mathrm{~kg} / \mathrm{m}^{2,17}$. The classification of UI was due to the symptoms of urine leakage ${ }^{1}$ reported in ICIQ-SF ${ }^{15}$. 
Nocturia was reported as a wake-up call one or more times at night to urinate or the recording of urination during one night's sleep ${ }^{18}$. The data were collected between July and October 2017. Data were tabulated and stored in the Office Excel 2010 program and imported into SPSS 17.0 software (Windows, Chicago, USA) for descriptive analysis by means of the calculation of absolute and relative frequencies.

The research follows the recommendations of Resolution 466 of 12/12/2012 of the National Health Council and was approved by the Committee of Ethics in Research with Human Beings of the Federal Fluminense University on July 13, 2017 with opinion 2.172.240 and Certificate of Presentation for Ethical Appraisal (CAAE) 36677514.0.0000.5243. All the volunteers signed the Term of Free and Informed Consent and received a copy of the document.

\section{RESULTS}

After applying the inclusion and exclusion criteria, the sample of this study ( $n=59)$ consisted of $35.32 \%$ of the student population of the project. It was observed that the age ranged from 60 to 89 years and had a mean of 71.4 years (standard deviation: 6.7). The sample presents $44.1 \%$ of its total in the age group between 70-79 years. The majority of the elderly women are widow (32.2\%), white (59.3\%), have completed high school (40.6\%) and live alone (52.5\%).

Regarding health data and lifestyle habits, the vast majority of women did not smoke (96.6\%) and 57.6\% did not drink alcohol. The majority did not suffer a fall event in the last year (64.4\%) and did not have fecal incontinence (84.7\%) nor intestinal constipation (71.2\%). The most significant comorbidities were hypertension (55.9\%) and osteopenia or osteoporosis (64.4\%). There was no report of Parkinson's disease and diabetes mellitus

Parity characteristics and births ways are shown in Fig. 1. Nulliparous represented 22\% ( $n=13)$ of the sample and the number of births was more frequent among those who had already performed between one and three, representing $71.2 \%(n=42)$ of the elderly. Regarding normal birth, $61 \%$ $(\mathrm{n}=36)$ never performed this type of birth and $32.2 \%$ $(\mathrm{n}=19)$ had between one and three births by this way. Regarding cesarean birth, 50.8\% $(\mathrm{n}=30)$ had a negative history and 49.2\% ( $n=29)$ had already performed between one and three by this way. It is worth emphasizing that each woman can have a history of more than one type of birth

There was a report of use of one to four medications daily in $57.6 \%$ of the sample, daily water intake of approximately $1 \mathrm{~L}$ in $57.6 \%$, overweight and adequate weight in $42.4 \%$ of the elderly in each of these two categories. Among the types of activities realized in the project, $45.8 \%$ of the sample practice stretching, while $28.8 \%$ do gymnastics and $25.4 \%$ exercise exercises.

Table 1 shows the results regarding conditions associated with urine loss. There was a predominance of UUI. There was a higher prevalence among those who report a loss of urine with frequency $\leq 1$ time per week, which its claim to be a small amount. Those that report losses in large and

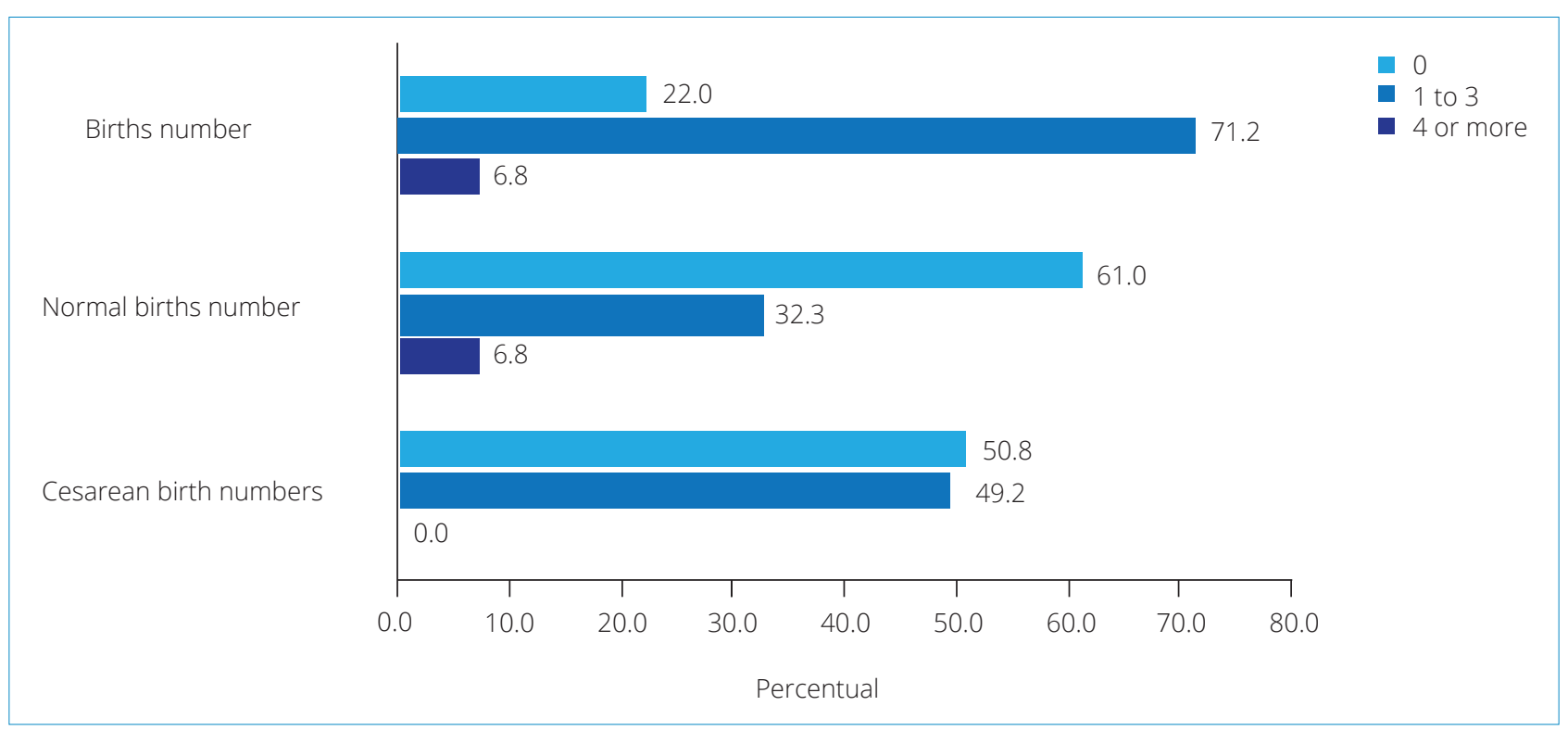

Figure 1. Percentage distribution of number and birth ways of physically active elderly women with urinary incontinence (UI) $(n=59)$. Niteroi, Rio de Janeiro, Brazil, 2017 
moderate amounts amount to $45.7 \%$, close to half of the sample. Regarding the type and situations of urine leakage variables with more than one response option - most reported a perceived jet loss before reaching the toilet. More than half identify UI symptoms between 1 and 4 years, 18.6\% show signs of nocturia and $67.8 \%$ do not make use of genital protectors, such as absorbent, cloth or geriatric diaper

As shown in Table 2, the majority of the elderly women who practice strength activities have UIU, as well as those who practice gymnastics and those who perform stretching activities. The least common type of UI in all types

Table 1. Conditions associated with urine loss in physically active elderly women with urinary incontinence (UI) ( $n=59)$. Niterói. Rio de Janeiro. Brazil. 2017.

\begin{tabular}{|c|c|c|}
\hline Variable & $\mathrm{n}$ & $\%$ \\
\hline \multicolumn{3}{|l|}{ Classification } \\
\hline Urgency & 30 & 50.9 \\
\hline Effort & 7 & 11.9 \\
\hline Mixed & 22 & 37.3 \\
\hline \multicolumn{3}{|l|}{ Frequency } \\
\hline$\leq 1$ timw a week & 25 & 42.4 \\
\hline 2 or 3 times a week & 17 & 28.8 \\
\hline Once a day & 11 & 18.6 \\
\hline Several times a day & 4 & 6.8 \\
\hline All the time & 2 & 3.4 \\
\hline \multicolumn{3}{|l|}{ Amount } \\
\hline Small & 32 & 54.3 \\
\hline Moderate & 17 & 28.8 \\
\hline Large & 10 & 16.9 \\
\hline \multicolumn{3}{|l|}{ Type } \\
\hline Drip & 25 & 42.4 \\
\hline Jet & 26 & 44.1 \\
\hline Continuous & 13 & 22.0 \\
\hline \multicolumn{3}{|l|}{ Situation } \\
\hline Sleeping & 10 & 16.9 \\
\hline Doing physical activity & 4 & 6.8 \\
\hline Coughing or sneezing & 27 & 45.8 \\
\hline Before getting to the bathroom & 50 & 84.7 \\
\hline Immediately after urinating & 4 & 6.8 \\
\hline No obvious reason & 3 & 5.1 \\
\hline All the time & 1 & 1.7 \\
\hline \multicolumn{3}{|l|}{ Time of symptom (years) } \\
\hline$<1$ & 7 & 11.9 \\
\hline $1-4$ & 38 & 64.4 \\
\hline $5-8$ & 8 & 13.5 \\
\hline$\geq 9$ & 6 & 10.2 \\
\hline
\end{tabular}

of activities is UIE; in particular, there are no reports of UIE among those who practice force activities.

Table 2. Percentage distribution of types of urinary incontinence (UI) as to the type of activity practiced in physically active elderly women $(n=59)$. Niterói, Rio de Janeiro, Brazil, 2017.

\begin{tabular}{lccc}
\multirow{2}{*}{$\begin{array}{c}\text { Type of activity } \\
\text { practiced in the project }\end{array}$} & \multicolumn{3}{c}{ UI Type - n (\%) } \\
\cline { 2 - 4 } & UIU & UIE & UIM \\
\hline Strength & $9(60.0)$ & - & $6(40.0)$ \\
\hline Gymnastics & $9(47.0)$ & $4(23.6)$ & $5(29.4)$ \\
\hline Stretching & $13(48.1)$ & $3(11.2)$ & $11(40.7)$ \\
\hline UIE = Effort Urinary incontinence; UIM = Mixed Urinary Incontinence; \\
UIU = Urgency Urinary Incontinence
\end{tabular}

\section{DISCUSSION}

Considering the sample size $(n=59)$ and the total number of elderly participants in the project $(n=167)$, it was verified that at least $35.42 \%$ are incontinent active elderly, which corroborates a study realized in the state of Santa Catarina ( SC) with active elderly women, in whom symptoms of urinary loss were present in $32.2 \%{ }^{13}$. The literature still presents few studies with investigations regarding the profile of physically active elderly with UI. The most found ones are performed in the elderly (not necessarily active) or institutionalized in adults and in athletes of modalities with high level of impact. The prevalence of urinary UI in these studies varies between 8 and $60 \%^{2,4-7}$ and depends, especially, on the age, gender, behavioral factors and life habits of the sample studied.

In this study, the highest concentration of incontinent active elderly women was between 70 and 79 years old (44.1\%), which is close to that of a population-based study in the state of Minas Gerais, which had $42 \%$ of incontinents in this age group ${ }^{2}$. In a representative sample of the population of the city of Florianopolis (SC), half of the incontinents were between 60 and 69 years old ${ }^{4}$. As in other analyzes ${ }^{2,4,13}$, the prevalence of UI in older elderly people was lower in this study (13.5\%). On the other hand, in a study realized in the state of São Paulo, the majority (30\%) of incontinent elderly individuals with fragility criteria are 80 years old or older, followed by $19 \%$ between 70 and 79 years. Age is one of the main risk factors for $\mathrm{UI}^{19}$, since there is greater exposure to physiological and hormonal changes due to aging, as well as behavioral factors ${ }^{5}$. 
Those who report having completed high school represent the largest portion of the sample (40.6\%). Studies indicate that low levels of schooling are associated with a higher incidence of $\mathrm{UI}^{4-5,19}$ and that the absence of schooling is related to an $83 \%$ higher chance of having $\mathrm{UI}^{2}$. This fact can be justified by the lack or difficulty of access to health information that individuals with lower schooling face, which may lead to the naturalization of UI symptoms among the elderly ${ }^{2}$. Thus, health education is an important strategy to disseminate fundamental information for this population, since, besides enabling the search for preventive and therapeutic actions for symptoms of urine loss ${ }^{4,19}$, it provides better conditions to deal with the daily challenges arising from $\mathrm{UI}^{2}$.

Regarding smoking, values close to that of this investigation (3.4\%) were found in $\mathrm{SC}^{4}$ and in a university hospital in the state of Piaui ${ }^{5}$, where only $8.3 \%$ and $2.1 \%$ were smokers, respectively. Smoking is a habit of life associated with UI, since the greater amount of tobacco in the body leads to estrogen deficiency, in addition to increasing coughing events - which favors the recurrent increase of intra-abdominal pressure -, conditions that can lead to $\mathrm{UI}^{7}$. Despite this, smoking and alcohol consumption were not presented as a risk factor in research conducted with active elderly women ${ }^{21}$.

Falls are frequent events in the elderly and have $\mathrm{UI}^{8}$ as a risk factor. Regarding this event, it is understood that incontinent patients are affected by musculoskeletal pelvic alterations that interfere negatively in the maintenance of postural balance and, associated with urinary urgencies, increased diuresis and nocturia, and environmental conditions, favor the occurrence of falls ${ }^{8}$. Despite this, $64.4 \%$ of the sample did not fall in the last year. It is believed that the physical activities practiced in the fall prevention project ${ }^{14}$ help to maintain the functional independence of these elderly women, and that staying physically active reduces the risk of falls and institutionalization ${ }^{8,10}$.

Parity and birth ways stand out as risk factors for UI among women. The prevalence of these variables is influenced by biological, cultural and economic factors ${ }^{19}$ and shows wide variations according to the sample profile. The study group had a higher frequency of women with one to three deliveries (71.2\%) and at least one cesarean birth (49.2\%), as observed in other studies ${ }^{7,12}$. On the other hand, other authors ${ }^{5}$ obtained values close to $70 \%$ of women with normal birth history and $43.8 \%$ of the cesarean type. Thus, parity seems to exert a greater influence on the appearance of UI than birth ways. In a study realized in $\mathrm{SC}^{18}$, a weak association between these variables was found, and it is stated that parity and birth ways do not increase the chances of UI, especially in the elderly population. There are studies that confirm parity as a risk factor ${ }^{7}$. Its point out that non-nulliparous women are 1.2 times more likely to have $\mathrm{UI}^{12}$ and that having a history of $\geq 2$ births, regardless by the way, increases the chance of having $\mathrm{UI}^{20}$ by $67 \%$. ICS advocates that both gestation and birth are risk factors for UI, and that the protective effect of cesarean does not persist after 50 years ${ }^{1}$.

Overweight is a characteristic of more than $40 \%$ of the sample. Studies indicate that overweight and obesity accentuate the intra-abdominal pressure exerted on the PFM, negatively affecting the mechanism of the urinary tract ${ }^{2,5,19}$, becoming determinant in the incidence and persistence of $\mathrm{UI}^{7}$. Despite this, overweight did not increase the chance of UI in research with active elderly women ${ }^{13}$, as well as in elderly in the community of Florianópolis ${ }^{4}$ and Pelotas ${ }^{19}$ (state of Rio Grande do Sul), where there was no relationship between UI and overweight variables.

Regarding the type of UI, the UIU had a higher prevalence $(50.9 \%)$. This value corroborates other studies with elderly women ${ }^{1,21}$. In a study conducted with 20.000 Chinese women, it was found that age greater than 60 years increases the chance of developing UIU ${ }^{22}$ twice. It is believed that the higher incidence of UIU in the elderly is justified by the structural alterations in the detrusor muscle from physiological aging ${ }^{21}$.

Although its are incontinent, only $32.2 \%$ of the sample makes use of some type of intimate protector, which may be related to the fact that the largest portion has symptoms of urine loss recently (64.4\%), with low frequency (42.4\%) and small amount (54.3\%). On the other hand, almost half of the sample (45.7\%) reported moderate or large urine loss. Studies indicate that small urinary losses cause behavioral changes that ease the repetition of these events and avoid embarrassment to the patients ${ }^{3,5}$. Reduced water intake, dark clothing, choice of public places next to restrooms, selfresuspension of diuretic drugs, and refraining from leaving home, among others, may mask the initial symptoms and delay the search for professionals in search of specialized treatments ${ }^{3,5}$.

It was observed that a larger proportion of the incontinent elderly women (45.8\%) practice stretching activities and a smaller proportion of them practice strength activities (25.4\%). In addition, there are no cases of UIE among force practitioners. These results suggest that there is a relationship 
between the type of activity practiced by the elderly women and the type of UI among them ${ }^{23}$. The practice of strength activities promotes the strengthening of the muscles of the lower limbs, abdomen, back and pelvic floor, favoring the reduction of UI symptoms ${ }^{24}$, which does not occur in stretching activities.

In Japan ${ }^{25}$, the UI status and habitual physical activity levels of 300 women with a mean age of 66.2 years were verified. Normal walking levels were lower among incontinent individuals compared to nonincontinent individuals. The prevalence of UI also decreased with the levels of total and moderate activity, but the corresponding reductions in risk were not statistically significant. Likewise, in a sample composed of 200 elderly women, it was verified that only the level of physical activity was associated with the occurrence of UIU, and physical exercise practice was a protective factor among low-active women (odds ratio (OR) $0.356,95 \%$ confidence interval $(\mathrm{CI}) 953-0133-0.953$, $\mathrm{p}$ value $=0.040)$ and very active (OR 0.288, CI 95\% 0.111-0.749, $\mathrm{p}$ value $=0.011)$, and that urinary urgency symptoms can be minimized regular physical exercise ${ }^{21}$. It is believed, therefore, that the regular practice of physical activities is a modifiable factor, since, besides favoring the reduction of episodes of urine loss, it influences the improvement of risk factors related to UI, such as hypertension, diabetes and polypharmacy ${ }^{21}$.

The limitations of this study are: restricted number of samples, classification of variables by self-report of volunteers, and lack of in-depth statistical analysis, elements that make it difficult to generalize the results. The relevance of this study is legitimate in that it is recognized that recent studies regarding the profile of active elderly women with UI are scarce and that this study adds data for this subject. In view of this, it is recommended to realize other studies in order to deepen knowledge on the subject and direct specific actions for this public.

\section{CONCLUSION}

This study made it possible to design the profile of elderly women with UI and regular physical activity practitioners in a fall prevention program in Niteroi. Its are mostly elderly women between the ages of 70 and 79 , widows, white women with a complete secondary level and living alone. Regarding the conditions associated with urine loss, incontinent elderly women report, in particular, moderate or large loss, with frequency less than or equal to once a week, and urgency characteristics. The profile of active elderly women with UI in this study resembles those found in the literature.

Some risk factors suggested by the literature were not expressive in this sample, such as smoking, last year's fall, fecal incontinence, intestinal constipation and polypharmacy. It is suggested that the practice of physical activities allows the adoption of a healthier way of life, favoring the reduction of these variables. Thus, it is believed that the multidisciplinary health team plays a fundamental role in stimulating the adoption of healthy habits that suppress the occurrence of UI and other important comorbidities, especially in the elderly. In addition, the prevention and early treatment of UI is recommended in order to avoid the worsening of symptoms and the quality of life of those affected by it.

\section{AUTHORS CONTRIBUTION}

Conceptualization, da Silva GGP and Krüger AP; Methodology, da Silva GGP and Alves Junior ED; Writing - First redaction, da Silva GGP and Krüger AP; Supervision, Alves Junior ED and Gurgel J; Writing - Second redaction - Review and Editing, da Silva GGP; Supervision, Alves Junior ED and Camacho ACLF.

\section{REFERENCES}

1. Abrams P, Cardozo L, Khoury AE, Wein A. Incontinence: 5th International Consultation on Incontinence. Paris: Health Publications; 2013;

2. Bolina AF, Dias FA, Santos NMF, Tavares DMS. Incontinência urinária autorreferida em idosos e seus fatores associados. Rev RENE. 2013;14(2):354-63.

3. Henkes DF, Fiori A, Carvalho JAM, Tavares O, Frare JC. Incontinência urinária: o impacto na vida de mulheres acometidas e o significado do tratamento fisioterapêutico.
Semina Cienc Biol Saúde. 2015;36(2):45-56. doi: 10.5433/1679-0367.2015v36n2p45.

4. Marques LP, Schneider IJC, Giehl MW, Antes DL, Orsi E. Fatores demográficos, condições de saúde e hábitos de vida associados à incontinência urinária em idosos de Florianópolis, Santa Catarina. Rev Bras Epidemiol. 2015;18(3):595-606. doi: 10.1590/19805497201500030006. 
5. Mourão LF, Luz MHBA, Marques ADB, Benício CDAV, Nunes BMVT, Pereira AFM. Caracterização e fatores de risco de incontinência urinária em mulheres atendidas em uma clínica ginecológica. ESTIMA, Braz. J. Enterostomal Ther. 2017;15(2):82-91. doi: 10.5327/Z1806-3144201700020004.

6. Silva VA, D'elboux MJ. Fatores associados à incontinência urinária em idosos com critérios de fragilidade. Texto \& Contexto Enferm. 2012;21(2):338-47. doi: 10.1590/S010407072012000200011.

7. Silva JCP, Soler ZASG, Wysocki AD. Fatores associados à incontinência urinária em mulheres submetidas ao exame urodinâmico. Rev ESC Enferm USP. 2017;5:e03209. doi: 10.1590/s1980-220×2016140903209.

8. Rosa TSM, Braz MM. Risco de quedas em idosos com incontinência: uma revisão integrativa. Rev Kairós. 2016;19(1):161-73.

9. Menezes EC, Virtuoso JF, Mazo GZ. Urinary loss in older women during physical exercise: a comparative study between aerobic and non-aerobic activities. J Phys Educ. 2016;27(1):1-10. doi: 10.4025/jphyseduc.v27i1.2712.

10. Binotto MA, Tassa KOME. Atividade física em idosos: uma revisão sistemática baseada no Internacional Physical Activity Questionnaire (IPAQ). Estud interdiscip envelhec. 2014;19(1):249-64.

11. Araujo MP, Parmigiano TR, Negra LGD, Torelli $L$, de Carvalho CG, Wo L, et al. Avaliação de assoalho pélvico de atletas: existe relação com incontinência urinária? Rev Bras Med Esporte. 2015;21(6):442-6. doi: 10.1590/1517869220152106140065.

12. Almeida PP, Machado LRG. A prevalência de incontinência urinária em mulheres praticantes de jump. Fisioter Mov. 2012;25(1):55-65.

13. Virtuoso JF, Menezes EC, Mazo GZ. Fatores de risco para incontinência urinária em mulheres idosas praticantes de exercícios físicos. Rev Bras Ginecol Obstet. 2014;37(2):82-6. doi: 10.1590/SO100-72032014000504.

14. Farinatti PTV, GuimaresJMN, Alves Junior ED. Envelhecimento e quedas: fatores de risco e prevenção. In: Farinatti PTV. Envelhecimento, promoção da saúde e exercício: tópicos especiais em aspectos biológicos e psicossociais. Barueri: Manole; 2013. v. 2.

15. Tamanini JTN, Dambros M, Dáncona CAL, Palma PCR, Netto Junior NR. Validação para o português do "International Consultation on Incontinence Questionnaire - Short
Form" (ICIQ-SF). Rev Saúde Publica. 2004;38(3):438-44. doi: 10.1590/S0034-89102004000300015.

16. Ministério da Saúde (BR). Vigitel Brasil 2015: vigilância de fatores de risco e proteção para doenças crônicas por inquérito telefônico. Brasília; MS; 2016.

17. Associação Brasileira para o Estudo da Obesidade e da Síndrome Metabólica. Diretrizes brasileiras de obesidade 2016. 4. ed. São Paulo: ABESO; 2016.

18. Abrams P, Cardozo C, Fall M, Griffiths D, Rosier P, Ulmsten $U$, et al. Standardisation Sub-Committee of the International Continence Society: the standardisation of terminology of lower urinary tract function: report from the Standardisation Sub-Committee of the International Continence Society. Urology. 2003;61(1):37-49. doi: 10.1002/nau.10052.

19. Carvalho MP, Andrade FP, Peres W, Martinelli T, Simch F, Orcy RB, et al. O impacto da incontinência urinária e seus fatores associados em idosas. Rev Bras Geriatr Gerontol. 2014;17(4):721-30. doi: 10.1590/1809-9823.2014.13135.

20. Danforth KN, Townsend MK, Lifford K, Curhan GC, Resnick SNM, Grodstein F. Risk factors for urinary incontinence among middle-aged women. Am J Obstet Gynecol. 2006; 94(2): 339-45.

21. Virtuoso JF, Mazo GZ. A prática de exercícios físicos é um fator modificável da incontinência urinária de urgência em mulheres idosas. Rev bras med esporte. 2013;19(2):84-7. doi: 10.1590/S1517-86922013000200001.

22. Zhu L, Lang J, Liu C, Xu T, Liu X, Li L. Epidemiological study of urge urinary incontinence and risk factors in China. Int Urogynecol J. 2010;21:589-93. doi: 10.1097/ gme.0b013e3181967b5d.

23. Virtuoso JF, Mazo GZ, Menezes EC. Prevalência, tipologia e sintomas de gravidade da incontinência urinária em mulheres idosas segundo a prática de atividade física. Fisioter Mov. 2012;25(3):571-82. doi: 10.1590/S010351502012000300013.

24. Kim H, Suzuki T, Yoshida Y, Yoshida H. Effectiveness of multidimensional exercises for the treatment of stress urinary incontinence in elderly community-dwelling Japanese women: a randomized, controlled, crossover trial. J Amer Geriatr Soc. 2007;55(12):1932-9. doi: 10.1111/j.15325415.2007.01447.x.

25. Lee AH, Hirayama F. Physical activity and urinary incontinence in older adults: a community-based study. Curr Aging Sci. 2012;5(1):35-4. doi: 10.2174/1874609811205010035. 